E Q U I L I B R I U M

Volume 6 IsSue 1, 2011

IS S N $1689-765 \mathrm{X}$

Tomasz Grzegorz Grosse Institute of Political Science Polish Academy of Science, Poland

\title{
Low Carbon Economy Policy in Poland: an EXample of THE IMPACT OF Europeanisation
}

JEL Classification Codes: $Q 3, Q 38, Q 48$

Keywords: low carbon economy, europeanisation, EU Climate and Energy Package

\begin{abstract}
Poland has made a commitment to reduce the emission of greenhouse gases by ratifying the Kyoto Protocol and by participating in the climate policy of the European Union (EU). EU Climate and Energy Package (CEP), which was negotiated in 2008 and has been successively introduced into the EU legal system. The CEP introduces much stricter requirements for the reduction of greenhouse gases emissions and imposes higher costs on the adjustment of Polish energy sector and other sectors of Polish economy to the requirements of the EU law. The influence of the EU on the Member States during the course of European integration is described in the literature of the subject as europeanisation. In this study I will analyse the influence on the policy of the Polish government with respect to stimulating the development of low carbon economy (including industry).
\end{abstract}

\section{The leading role of europeanisation}

Poland has made a commitment to reduce the emission of greenhouse gases by ratifying the Kyoto Protocol ${ }^{1}$ and by participating in the climate policy of the European Union (EU). The above commitments have the influence on a number of areas of Polish government's activity, including environment, energy and eco

${ }^{1}$ Kyoto Protocol - supplements the United Nations Framework Convention on Climate Change, which was signed in Rio de Janeiro in 1992. The Protocol was negotiated in Kyoto in December 1997. The Treaty came into force in 2005. See The Kyoto Protocol to the United Nations Framework Convention on Climate Change, adopted in Kyoto on 11 December 1997, "Journal of Laws". 
nomic sectors. The law of the European Union binding for all the Member States makes a particularly significant impact. That applies primarily to the EU regulations known under the name of the EU Climate and Energy Package (CEP), which was negotiated in 2008 and has been successively introduced into the EU legal system. The above-mentioned regulations make a much stronger impact in Poland than the United Nations Framework Convention on Climate Change adopted in Kyoto. In the area of environmental protection, the EU law has the priority of application over other international obligations. In addition, the CEP introduces much stricter requirements for the reduction of greenhouse gases emissions and imposes higher costs on the adjustment of Polish energy sector and other sectors of Polish economy to the requirements of the EU law (Jeszke et al. 2009, p. 13; Pyrka et al. 2009, p. 8; Zielona Księga... 2010, p. 29; Ocena potencjatu redukcji... 2009; Energy and $\mathrm{CO}_{2}$ emissions... 2010; Transition... 2011; Żmijewski 2011b). The influence of the EU on the Member States during the course of European integration is described in the literature on the subject as Europeanisation (Börzel 2005; Börzel et al. 2007; Cowles et al. 2001; Featherstone et al. 2003; Mair 2004; Radaelli 2003; Olsen 2002). In this study I will analyse the influence on the policy of the Polish government with respect to stimulating the development of low carbon economy (including industry).

The CEP targets are commonly referred to as " 3 times 20 for 2020 " and are as follows:

- To achieve $20 \%$ increase in energy efficiency in relation to the BAU scenario $^{2}$ by the year 2020 ;

- To increase the share of energy from renewable sources up to $20 \%$ of the final energy consumption in the EU by the year 2020;

- To reduce by at least $20 \%$ the emission of greenhouse gases in relation to 1990 levels by the year 2020, with an option of further reduction even to $30 \%$, provided that other developed countries commit themselves to a similar reduction of emissions and the selected developing countries make an appropriate contribution, adequate to their reduction capabilities. It is worth noticing that some European politicians insist (Hedegaard backtracks... 2010; Climate change... 2010) that the EU should make a unilateral commitment to reduce gas emissions by $30 \%$ regardless of the position taken by countries outside Europe. In addition, the European Commission proposes a further reduction of emissions in 2050 by $80-95 \%$ relative to 1990 levels (A Roadmap... 2011).

In Poland it is particularly difficult to meet the CEP criteria. There are several factors that make it so. The first one is the very poor condition of Polish energy infrastructure. Experts' estimates show (Zielona Księga... 2010, pp. 32-35) that

${ }^{2} \mathrm{BAU}-($ business as usual) - a scenario in which no additional action is foreseen with respect to energy efficiency. 
about $40 \%$ of power generating units are over 40 years old. $15 \%$ are over 50 and they should be immediately stopped and disconnected from the grid. More than $70 \%$ of power units are 30 years old or older. Decapitalisation of power plants exceeds $73 \%$, of transmission networks $71 \%$, distribution networks $75 \%$ and the depreciation of the heating sector exceeds $63 \%$. The already poor condition of the infrastructure is worsening systematically and this phenomenon has been counteracted neither by the process of privatisation of the energy sector nor by commercial or public investment of recent years. Their scale is too small as compared to the needs and, in addition, the projects are often blocked by some formal or legal ambiguities arising from the implementation of CEP. The main issue is the protracted work of the EU institutions on the details of the Package and especially the scope of the free emission allowances for the energy sector in the years 2013-2020 (Piszczatowska et al. 2010; Piszczatowska 2011; Łakoma et al. 2011). Polish government's estimates (Polska 2030... 2009, pp. 176, 180$-181)^{3}$ show that in the coming years it will be necessary to double the existing energy generating capacity. Investment in modernisation and in new capacity should reach PLN 86 billion (21.5 billion euro) by 2015 and another PLN 49 billion (12.2 billion euro) by the year 2030. Without this investment, energy deficit will appear as early as 2011 . It will reach about $25 \%$ in relation to the needs by the year 2030 (in a scenario where the necessary modernisation has not been carried out) (see Figure 1). What is more, the depreciation of the energy infrastructure is the reason why the potential of emissions reduction in Poland by the year 2020 is only 3 percent (in relation to the year 2005). Any possibilities of growth of this potential appear only after 2020, provided that significant investment will have been made (Ocena potencjatu... 2009, p. 10).

Secondly, the energy sector in Poland is not very efficient, which is in part caused by the poor condition of the infrastructure. The energy intensity of the economy is one of the highest in the European Union (see Figure 2). According to the government's estimates (Polska 2030 2009, p. 172) it is approximately three times higher than in the "old" Member States (EU15). It is worth noting that the level of energy intensity went down significantly in the 1990s as a result of the deindustrialisation which accompanied the economic transformation process as well as the improvement of economic effectiveness of the remaining enterprises adapting to the free market conditions. Privatisation and the inflow of new technologies together with the new industrial investment also played an important role.

${ }^{3}$ Some experts point out that the demand for energy will indeed grow but it will still be smaller than the estimates included in the report Polska 2030 (see Karaczun et al. 2009, p. 53). 
Figure 1. Estimated energy deficit 2011-2030

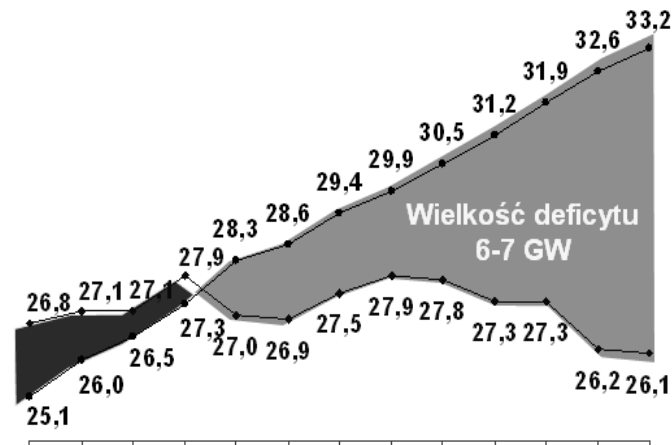

2008200920102011201220132014201520162017201820192020

Sources: Polska 2030, Prime Minister's Chancellery, Warsaw 2009, p. 180.

Figure 2. Energy intensity of the economy (kg of oil equivalent per EUR 1000 of GDP)

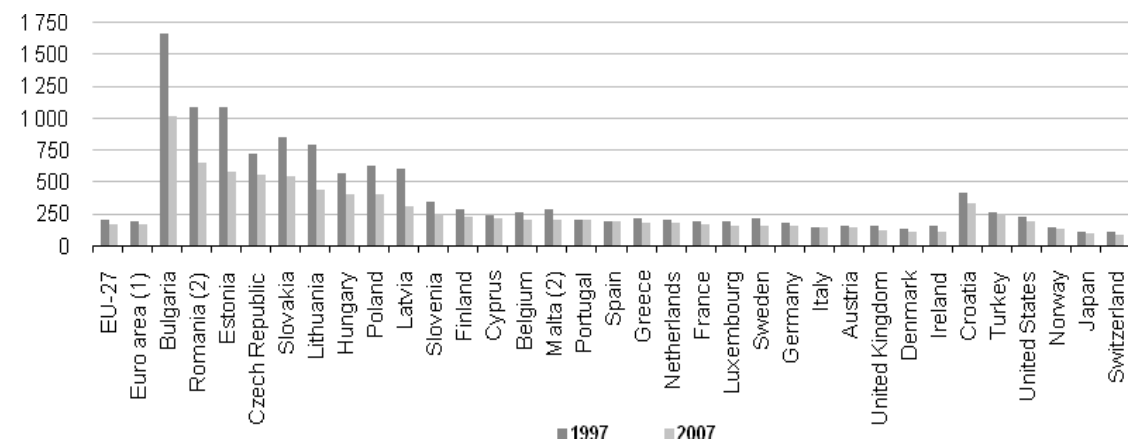

Sources: Europe in figures. Eurostat yearbook 2010, Eurostat 2010.

Thirdly, close to $90 \%$ of energy in Poland is generated from coal and lignite (the EU average is less than 30\%). This results from the fact that Poland's own coal resources are relatively big, which is the reason why a coal-based economy is of great significance in Poland as far as the national energy security is concerned. It is, however, a high emission source of energy, generating twice as much $\mathrm{CO}_{2}$ as natural gas. That is why the implementation of CEP is much more expensive in Poland than in other EU countries, for example in those which base their energy generation on gas (the Netherlands, Italy, Ireland, the United Kingdom), nuclear energy (France, Sweden, Belgium, Lithuania, Slovakia) or renewable sources (Austria, Latvia, Sweden, Finland). The share of energy from renewable sources (RSE) in Poland in 2008 reached only 7.6\%, whereas the EU 
average was at that time close to 18\% (Energia ze źródet odnawialnych ... 2010, p. 18). According to the government experts (Zielona Księga ... 2010, p. 89), it will be difficult to achieve the CEP targets in this respect (for Poland they are $15 \%$ RSE by 2020). As a result, Poland is one of the biggest emitters of greenhouse gases in the EU (see table 1). In relation to the potential of its economy (measured with the GDP purchasing power parity) Poland is one of the countries with highest investment needs and poorest possibilities of their fulfilment. Most of the new EU Member States from Central Europe belong to that group.

Therefore, with respect to energy and climate policy, Europeanisation forces Poland (and other countries of Central and Eastern Europe) to bear high adjustment costs. They may have some serious consequences for the functioning of individual economies, they may also reduce their competitiveness in the costeffectiveness aspect, both in the common market and in the global trade. Even more so as the CEP does not take into account the specific nature of those countries' energy sectors (e.g. it does not make a distinction between the more difficult starting points of the coal-based economies). In principle, it does not take into account the difference in the level of development of individual countries, either. For example, the division of the emission rights introduced in the EU (the so called EU ETS) assumes that only 10 percent of the rights will be distributed on the basis of the GDP per capita criterion ${ }^{4}$. That makes a fundamental difference in comparison to the Kyoto Protocol, where the former socialist countries were treated less strictly and were expected to reduce their emissions only by 6 percent in relation to 1988 levels. According to the experts, Poland has more than fulfilled that target (having reduced its emissions relative to the base year by approx. 30 percent) (Karaczun et al. 2009, p. 44). The Climate and Energy Package has not only introduced higher targets but it has also failed to take into account the reduction made in post-socialist countries in the 1990s. This is connected with the fact that under the EU system for managing the green house gases emissions, the year 2005 has been adopted as the main reference point and, in addition, the Community emission trading scheme (EU ETS) calculates the emission allowances (and the related reduction) for the entire Union.

Specialists also point to other elements of the CEP which are disadvantageous for the less vigorously developing economies of Central Europe. For instance, the allocation of the free emission rights in the years 2013-2020 for the industrial sectors threatened with relocation of production ("emissions leakage") is made on the basis of the benchmarks from the most effective and technologically advanced installations in the European Union. It is beneficial for the best

\footnotetext{
${ }^{4}$ For this reason, in the years 2013-2020 Poland may count on only 30 million emission rights, which accounts for less than 1 percent of the total number of emission rights for that period of time (see R. Jeszke et al. 2009, p. 9).
} 
Table 1. Greenhouse gas emissions

\begin{tabular}{|c|c|c|c|c|c|c|c|}
\hline \multirow[t]{2}{*}{ Countries } & \multicolumn{2}{|c|}{$\begin{array}{c}\mathrm{CO}_{2} \text { emissions / } \\
\text { GDP (PPP) } \\
(\mathrm{kg} \mathrm{CO} / 2000 \\
\text { USD) }\end{array}$} & \multicolumn{5}{|c|}{$\begin{array}{l}\text { Weighted emissions of greenhouse gases } \\
\text { (million tonnes of } \mathrm{CO}_{2} \text { equivalent) }\end{array}$} \\
\hline & 2008 & Rank & 1997 & 2002 & 2007 & $\begin{array}{c}\text { Share in } \\
\text { EU-27 (\%) }\end{array}$ & Rank \\
\hline EU-27 & & & - & 5065.7 & 5045.4 & - & \\
\hline Euro area & : & & 3365.1 & 3414.5 & 3364.1 & 66.7 & \\
\hline OECD & 0.38 & & & & & & \\
\hline Belgium & 0.34 & & 145.1 & 142.9 & 131.3 & 2.6 & \\
\hline Bulgaria & 0.64 & 2 & 83.8 & 66.5 & 75.8 & 1.5 & \\
\hline $\begin{array}{l}\text { Czech } \\
\text { Republic }\end{array}$ & 0.54 & 3 & 153.0 & 145,1 & 150.8 & 3.0 & \\
\hline Denmark & 0.28 & & 79.8 & 68,6 & 66.6 & 1.3 & \\
\hline Germany & 0.34 & & - & 1006.4 & 956.1 & 19.0 & 1 \\
\hline Estonia & 0.78 & 1 & 21.3 & 18.1 & 22.0 & 0.4 & \\
\hline Ireland & 0.28 & & 62.8 & 68.8 & 69.2 & 1.4 & \\
\hline Greece & 0.34 & & 118.1 & 127.8 & 131.9 & 2.6 & \\
\hline Spain & 0.29 & & 332.7 & 403.1 & 442.3 & 8.8 & 5 \\
\hline France & 0.21 & & 564.6 & 549.3 & 531.1 & 10.5 & 4 \\
\hline Italy & 0.28 & & 528.7 & 555.8 & 552.8 & 11.0 & 3 \\
\hline Cyprus & 0.42 & 5 & 7.5 & 9.3 & 10.1 & 0.2 & \\
\hline Latvia & 0.24 & & 12.0 & 10.7 & 12.1 & 0.2 & \\
\hline Lithuania & 0.26 & & 22.6 & 20.6 & 24.7 & 0.5 & \\
\hline Luxembourg & 0.33 & & 9.8 & 11.3 & 12.9 & 0.3 & \\
\hline Hungary & 0.33 & & 79.9 & 78.0 & 75.9 & 1.5 & \\
\hline Malta & 0.33 & & 2.6 & 2.8 & 3.0 & 0.1 & \\
\hline Netherlands & 0.33 & & 225.9 & 215.5 & 207.5 & 4.1 & \\
\hline Austria & 0.25 & & 83.1 & 87.0 & 88.0 & 1.7 & \\
\hline Poland & 0.53 & 4 & 449.1 & 371.5 & 398.9 & 7.9 & 6 \\
\hline Portugal & 0.28 & & 71.4 & 88.8 & 81.8 & 1.6 & \\
\hline Romania & 0.41 & 6 & 166.7 & 146.7 & 152.3 & 3.0 & \\
\hline Slovenia & 0.34 & & 19.6 & 20.1 & 20.7 & 0.4 & \\
\hline Slovakia & 0.38 & & 49.9 & 49.0 & 47.0 & 0.9 & \\
\hline Finland & 0.34 & & 75.7 & 76.8 & 78.4 & 1.6 & \\
\hline Sweden & 0.15 & & 72.6 & 69.6 & 65.4 & 1.3 & \\
\hline $\begin{array}{l}\text { United } \\
\text { Kingdom }\end{array}$ & 0.28 & & 708.1 & 655.8 & 636.7 & 12.6 & 2 \\
\hline
\end{tabular}

Sources: Europe in figures. Eurostat yearbook 2010, Eurostat 2010; 2010 Key World Energy Statistics, International Energy Agency 2010. 
developing countries with modern energy sector and the economies highly sat urated with energy efficient technology. The allocation of emission rights does not take into account the fuel specificity of individual economies, which will be unfavourable for the countries with coal-based economies (Jeszke et al. 2009, p. 13; Pyrka et al. 2009, p. 8; Zielona Ksiega ... 2010, p. 29). Some industries in Poland [...] will receive fewer emission rights needed for production than their competitors in other EU Member States" (Pyrka et al. 2009, p. 38). It is estimated that for this reason, Polish economy will receive approximately $30 \%$ fewer emission rights (Smol 2010, p. 11). That is why experts foresee a possibility of reduction of foreign investment in the sensitive sectors or relocation of production to other EU Member States with lower production costs (Pyrka et al. 2009, p. 9). In Poland, the enterprises that belong to the most energy intense sectors are the most threatened: smelting, chemical and refinery sectors, mineral and paper sectors (Pyrka et al. 2009, pp. 13, 16, 39; Efektywność wykorzystania energii... 2010, pp. 44-45). Some sectors have not been included by the European Commission (EC) on the list of free emission rights at all because of the risk of "emissions leakage".

Poland has found itself in the group of states enjoying the right of derogation of the paid emission rights in the power generation sector in the years 2013-2020 (it has received up to 70 percent of free emission rights in 2013, to be gradually reduced in the subsequent years). It will probably slow the pace of the energy price hikes for companies and individual consumers. Nevertheless, the European Commission exerts pressure on Poland to make it use the free emission rights to the least possible extent (Bruksela ... 2011). It has also proposed to link the derogation with additional investment in CCS installations ${ }^{6}$. The prolonged negotiations have almost completely frozen the investment in the energy sector in Poland (Elektrownie... 2010), and they even prompt some companies to withdraw from the Polish market (Członek zarzqdu... 2011); whereas, in the sectors not included in the EU ETS (transport, agriculture, housing etc.), Poland has the possibility to increase the emissions by $14 \%$. According to experts ${ }^{7}$ the forecasted growth of emissions in the years 2005-2030 amounts here to as much as $68 \%$, which is the reason why the decision of the EC is highly insufficient. The growth of emissions in transport is, to a great extent, stimulated by transport sector investment projects funded from EU funds.

In conclusion, it should be noted that the consequences of introducing the CEP will be particularly strong in the countries with a disadvantageous energy

${ }^{5}$ In Poland that applies to the manufacturers of bricks and roof tiles (see Jeszke et al. 2009, p. 17).

${ }^{6} \mathrm{CCS}$ (Carbon Capture and Storage): installations for capturing and storage of $\mathrm{CO}_{2}$ (see Unia uderzy w inwestycje... 2011).

7 Statement made by A. Kassenberg during the conference „Droga ku efektywnemu wdrażaniu PEK" [Towards effective implementation of CEP], 18 November 2009, Warsaw. 
mix and at the same time weaker economies. In the case of Poland, the necessary investment is estimated to be at the level of 92 billion euro by the year 2030 (Ocena potencjatu... 2009, p. 17). Experts of the International Energy Agency (Energy and $\mathrm{CO}_{2} \ldots 2010$, p. 4) estimate the total costs of the implementation of CEP and the enhancement and modernisation of the energy infrastructure in Poland to amount to 195 billion euro at the same time. Domestic experts (Zielona Ksiegga... 2010, p. 31) assume that even higher costs will be involved: from 265 to 320 billion euro. The scale of this investment is disproportionate to the level of economic development.

According to some estimates, the huge scale of investment imposed by the CEP will bring GDP growth and increase of employment in the whole European Union. According to German experts (A New Growth... 2011, p. 9), the reduction of $\mathrm{CO}_{2}$ emissions to the level of 30 percent will increase the EU GDP in 2020 by $5.7 \%$ and will reduce the number of the unemployed by more than $30 \%$. These estimates do not, however, take into consideration the negative economic consequences. The predictions for Poland include an increase in the production costs, lower competitiveness of the economy and outflow of production investment outside the country. According to EU experts (ReRisk Regions... 2010, p. 2), in Poland, the employment in the sectors at risk of transfer abroad of high emission and energy-intensive industries, is the highest in the EU and exceeds $9 \%$ of all people employed in industry (the average rate for the EU is less than 3\%). This means that in the face of a significant scale of investment, business may be more willing to transfer the production than to bear the high costs. According to World Bank experts, implementation of the CEP in Poland will have adverse effects on the speed of economic growth, at the average annual level of 1 percent of GDP by the year 2030. The years around 2020 will be the most difficult ones. Then, the costs of the Package may reach even 2 percent of GDP. It is also possible that employment will fall annually, by 140 thousand people on average (approx. 1 percent of all the employed) (Transition... 2011, pp. 15-17). The estimates of Polish experts are even more alarming (average 2\% fall of GDP and an almost 2 percent rise in unemployment) (Żmijewski 2011b, p. 5). Thus, Europeanisation brings asymmetrical consequences for individual EU Member States, it is more beneficial for the richer economies, with better-developed environment-friendly technology and less dependent on coal. In addition, the European policy does not take into consideration the domestic energy resources in Poland, which is an aspect of economic security.

At this point, it is worth noting that the methodology of setting the emission reduction targets adopted by the EU, has so far proved to be an ineffective mechanism in the external policy. This has been shown by the fiasco of the negotiations started during the climate conference at Copenhagen (Gradziuk et al. 2010). The European efforts to contain the climate warming have not brought the expected results of stopping the growth of global temperature. This applies 
in particular to the unilaterally adopted tactic of limiting emissions. It does not have any great significance for climate change (Europe accounts for only $14 \%$ of the global greenhouse gases emissions); nor does it encourage the expected response of the remaining parties to the UN Framework Convention.

However, many experts point that the activities of the EU have also other serious political and economic goals, apart from the environmental motivation. They are, among other things, connected with an attempt on the part of the EU to play a greater role in international politics (as the so called normative power) (Scheipers et al. 2007), as well as to strengthen the role of the Community institutions (e.g. EC) in the EU external policy (Schreurs 2004; Costa 2008). Another political goal is to strengthen the public approval for European integration, which results from the favourable attitude to ecology in most of the western European societies (Schreurs et al. 2007). Apart from that, the economic goals are more and more visible. They concern strengthening of the competitiveness of some European economies, globally and on the common market. The point is mainly to capitalise on the advantage in the access to low carbon technology and cleaner energy sources (Hongyuan 2009). This is clearly shown by the documents of the European Commission where the benefits generated by global technological competition are used as the main argument for the need to further increase the $\mathrm{CO}_{2}$ reduction targets in the EU (Analysis of options... 2010; A Roadmap... 2011, pp. 5, 12).

What is particularly interesting is the impact of CEP on the competitiveness of individual economies of EU countries. As I have mentioned, the process of Europeanisation is clearly asymmetrical in this respect. It is advantageous for the better-developed countries with technological advantage and at the same time, it imposes serious burden on weaker economies and those based on coal, thus lowering their competitiveness in the area of cost-effectiveness. This is related to strong economic competition on the common market and to attempts by individual EU member States to use EU regulations to increase their economic benefits (Smith 2005; Callaghan et al. 2005). It is shown by the strong pressure of the biggest net contributors to the EU budget to preserve the financial transfers of the cohesion policy for the weakest members of the Community under the condition that they accept the higher, that is $30 \%$ reduction of $\mathrm{CO}_{2}$ by the year 2020 (Czy zbankrutujemy... 2010).

\section{Strategy of the Polish government for the support of low carbon economy}

The worsening collapse of the energy infrastructure in Poland has not proved to be a sufficient reason for subsequent governments to undertake appropriate strategic 
action. It shows the weakness of the long-term economic policy of the state ${ }^{8}$. Polish climate policy has emerged under the influence of the ratification of the Kyoto Protocol. It should, however, be noted that it has not included any active economic policy of the government as the reduction of emissions took place spontaneously, as a result of industrial restructuring during the system transformation and the privatisation process. This has even prompted the Polish government to adopt an ambitious emissions reduction target of $40 \%$ by the year 2020 relative to the base year of 1988 (Polityka Klimatyczna Polski... 2003, p. 14).

The situation has changed following the European integration, and especially under the influence of the Climate and Energy Package ${ }^{9}$. Poland has started various planning activities, which initially concerned mainly the area of ecology and only later touched upon the economy (mainly the energy sector, and, to a lesser extent, other sectors). The actions of the Polish authorities are therefore taken, to a great extent, in reaction to the European regulations and policies. Their primary role is to implement the Europeanisation requirements and to a much lesser extent - to pursue the long-term national interests. What is more, they are implemented with significant delay (in relation to the strategic discussions at the EU level). Another drawback is the political passivity in the European arena (Karaczun et al. 2009, p. 45). Poland joined the CEP negotiations too late, without proper preparation based on estimating the costs for Polish economy of implementing the Package ${ }^{10}$. For example, appropriate statistical data concerning Polish voivodships were not submitted. As a result, the EU documents (ReRisk Regions 2010, p. 14-15) have not included Polish regions among those most threatened with the transfer of the high emission and energy intensive industries ${ }^{11}$. This shows the weakness of the long-term economic policy, which, in the conditions of European integration, requires active participation in the planning of European policies. It is also clear that there is no political continuity of the subsequent governments and both the documents and the strategic goals are widely dispersed, especially at the ministry level. What is more, they are not sufficiently coordinated ${ }^{12}$.

The main strategic document in the recent years has been the National Development Strategy 2007-2015 (NDS) adopted in the autumn of 2006 (Strategia

\footnotetext{
${ }^{8}$ On the weakness of the Polish government economic policy, among others: Klonowski 2010; Grosse 2010a.

${ }^{9}$ An interview with D. Ledworowski (Public Board for the national Programme of Emissions' Reduction), March 2011; an interview with T. Chruszczow (Ministry of Environment), March 2011.

${ }^{10}$ An interview with A. Kassenberg (Institute for Sustainable Development), March 2011; an interview with D. Kulczycka (PKPP Lewiatan), March 2011; an interview with D. Ledworowski (Public Board for the National Programme of Emissions' Reduction), March 2011.

${ }^{11}$ This point is also made by: Żmijewski (2011b, p. 10).

${ }^{12}$ An interview with A. Błachowicz (Ministry of Environment), March 2011.
} 
Rozwoju Kraju... 2006). After the change of government in 2007 the document became only a front, without any great political significance. Even though the new cabinet adopted initial proposals for an update of the NDS (Założenia aktualizacji... 2008), yet it later practically suspended any work on that and began to prepare a separate document designed to be a long-term strategy for national development. By the end of the government's term in office such a document was not produced. In this situation, the fundamental documents setting the government policy for the years 2007-2011 are the National Reform Plan for the years 2008-2011 (NRP) (Krajowy Program Reform... 2008) and the National Strategic Reference Framework 2007-2013 (NSRF) (Narodowe Strategiczne Ramy Odniesienia... 2007). Both documents have been prepared under the influence of the European Union and for the purposes of the EU policies and funds. The former was supposed to implement the Lisbon Strategy in Poland, whereas the latter implements the cohesion policy. Table 2 shows a list of the main priorities included in the above-mentioned documents.

In the strategic documents under analysis, six main priorities can be found. They all refer to the higher goal of building the competitiveness of Polish economy. Among the priorities, three seem to be of the greatest importance for the state's economic policy: (1) development of innovative economy, (2) infrastructure for the purposes of economic competitiveness and (3) human capital. The priority concerning institutional development aims at improving the effectiveness of the implementation of public policies, and especially the implementation of the policies, regulations and funds of the EU, whereas the remaining priorities concerning development of rural areas and regions in fact implement the already mentioned priorities within the territorial system of the country.

All the documents under analysis refer to the EU CEP. However, they refer to the objectives of the low carbon policy and development of the energy sector only in a very general way (table 3 ). They focus on environmental protection and not on supporting the national economy in order to facilitate the adjustment to the requirements of Europeanisation. Having read those documents one finds it difficult to talk about the existence of a "green" industrial policy or a low carbon economic policy of the Polish government. The NDS is an exception here as it assumes the preparation of multi-annual programmes for the development of individual industries while assuring the fulfilment of the low carbon economy objectives and adapting to EU environmental regulations (Strategia Rozwoju Kraju... 2006, pp. 38, 46). This can be seen, for instance, in the fact that even though the Polish government documents are prepared in response to the action taken by the European Union, in some areas it happens with a significant delay in relation to the work at the European level.Meanwhile, in the most recent economic strategy of the EU "Europe 2020", one of the most important development instruments is the "green" industrial policy (Europe 2020 ... 2010, pp. 1216). In addition, the EU laws allow for public aid to the sectors threatened with 


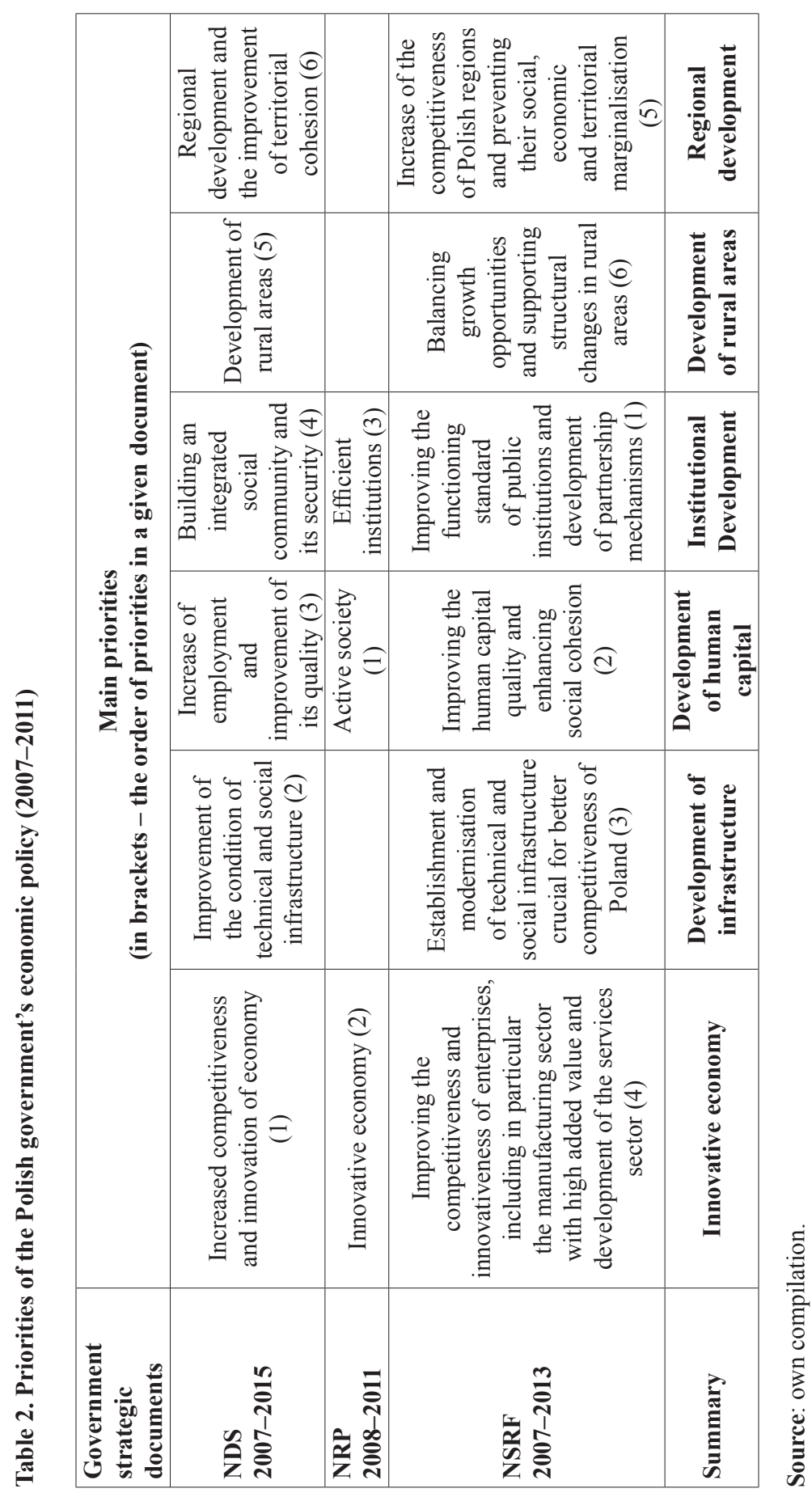




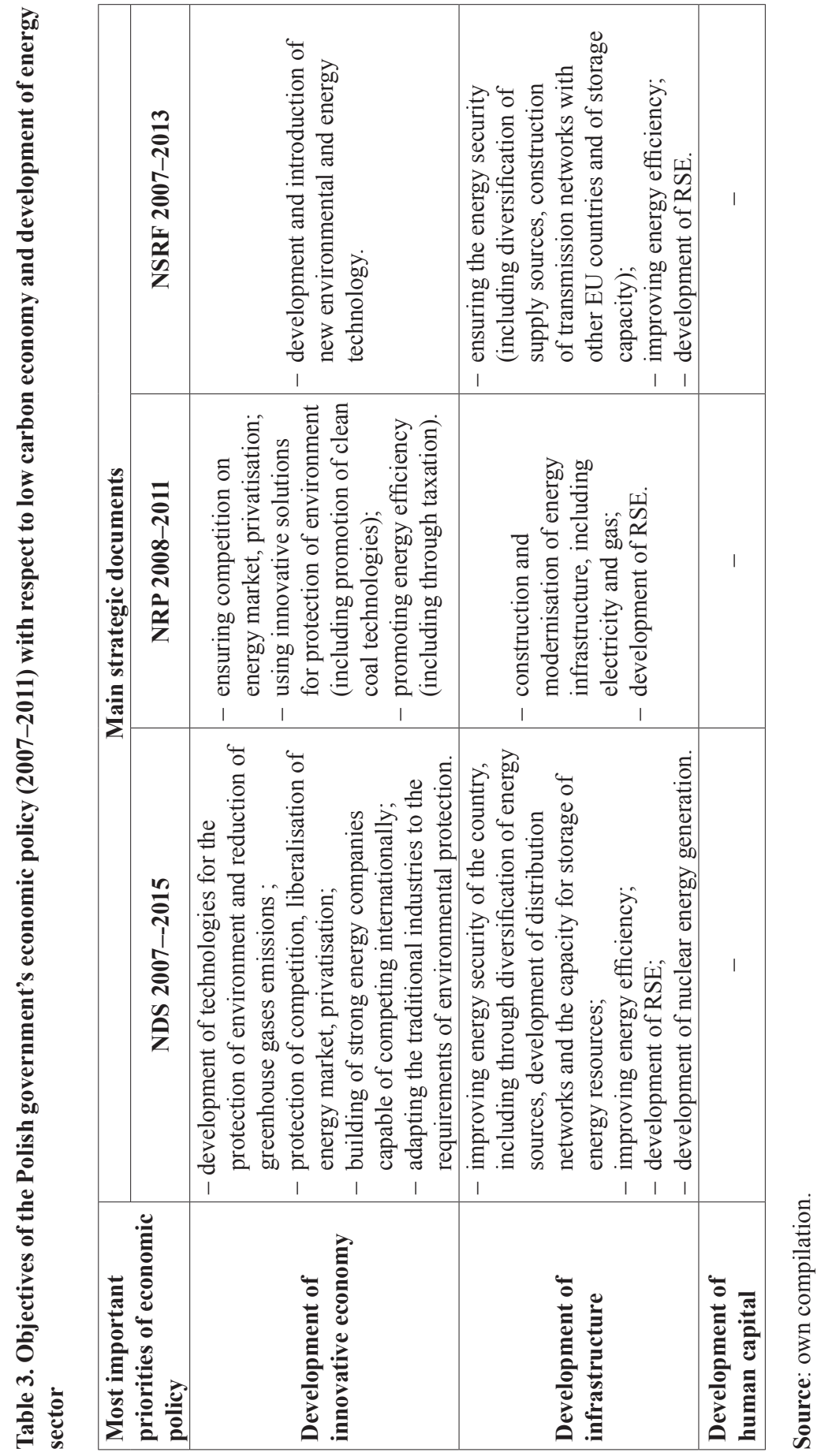


high costs of energy purchase and relocation of production abroad. Nevertheless, the EU regulations are not precise and, in addition, Poland has limited possibilities to grant aid in a situation where the public debt is growing.

In none of the strategic documents under analysis there could be found proposals for action for human capital development which would be related to low carbon economy. Thus, one of the three main priorities of the economic policies of subsequent governments has not been practically included in the planning for emissions reduction. An additional problem is the fact that Poland does not have a tradition of preparing political strategies oriented towards solving one particular problem which would combine the activities of several ministries at the same time. For instance, there is no strategy for low carbon industrial policy that would coordinate the action of various ministries and at the same time would ensure the implementation of the main priorities of the government's economic policy ${ }^{13}$. Even though in 2010, in the Ministry of Economy, the main assumptions of the National Programme for the Reduction of Greenhouse Gases Emissions (Załozenia Narodowego Programu... 2010) were prepared, yet it is a document of a very general nature. It contains only some initial proposals for action which is in principle within the remit of the Ministry of Economy. Experience shows that individual ministries prepare their own sector-specific strategies which usually cover rather narrowly outlined tasks of a given ministry. The only exception is documents prepared by the Ministry of Regional Development (that is where NDS and NSRF have been produced). It was only in December 2010 that an inter-ministerial working group was formed whose task is to prepare the National Plan for the Development of Low Emission Economy, which will provide the basis for the low carbon economic policy of the Polish government. In view of the coming parliamentary elections, however, it is not at all clear whether this policy will be drafted in the near future.

A number of sector-specific documents may be mentioned here which have been prepared recently and which aim at implementing the EU CEP in Poland (Polityka ekologiczna... 2008; Krajowy Plan Działań... 2007). Experts note ${ }^{14}$ that in Poland, the climate policy has never been integrated with the economic policy. A strategy that, to the greatest extent, points to the government priorities related to low carbon economy is currently only the Polish Energy Policy until the year 2030 (PEP) (Polityka energetyczna Polski... 2009). It refers directly to the CEP, and the three main objectives of the Package have been transferred directly as priorities of the strategy. Thus, the Polish energy sector strategy fo-

${ }^{13}$ An interview with A. Kassenberg (Institute for Sustainable Development), March 2011; an interview with D. Kulczycka (PKPP Lewiatan), March 2011; an interview with M. Sobolewski (Bureau of Research, Chancellery of the Sejm), March 2011; an interview with D. Ledworowski (Public Board for the National Programme of Emissions' Reduction), March 2011.

${ }^{14}$ Statement made by A. Kassenberg during the conference „Droga ku efektywnemu wdrażaniu PEK" [Towards effective implementation of CEP], 18 November 2009, Warsaw. 
cuses more on the implementation of the CEP and less on the implementation of the national economic policy. This is clearly visible on the example of the rather scarce support instruments addressed to enterprises. Similarly, as in the other documents described above, one of the main mechanisms for adapting the industry to EU regulations is market liberalisation, which leads largely to shifting the cost of new investment projects to energy consumers. The government is also trying to increase the obligations of local governments with respect to investment projects. An important priority of this strategy is the energy security. As I have mentioned before, in this respect the requirements of the CEP are a real challenge for Polish economy based on coal (and our own coal resources). That is why the government's energy policy leads not only to diversification of directions of energy supply, construction of storage capacity, etc. but also to diversification of the energy mix. The point is to reduce the dominating position of coal as the energy source in Poland. Table 4 shows the planned objectives and activities of Polish government for reduction of greenhouse gases emissions. They have been prepared on the basis of PEP.

\section{Implementation of action in support of low carbon economy}

Since the planning of strategic action for low carbon economy has started in Poland quite recently - its implementation has also been delayed. Therefore, it is rather difficult to assess its effectiveness, especially, as some experts view the government's activity as mere declarations which are not effectively implement$\mathrm{ed}^{15}$. An additional difficulty is the lack of a leading strategic government document both on the economic policy and in relation to low carbon industrial policy. As a result, there is no coherent system of monitoring and evaluation of those policies. Still another problem is posed by the dispersion of the works and planning documents within Polish government. That results in the lack of proper cooperation during the implementation stage.

Because of budget restrictions and the lack of industrial policy tradition after the political system transformation in 1989, legislation is the main area of government activity. This applies particularly to the implementation of the EU law. The work has, however, been delayed. An example can be a few months lag in introducing into the national legal system of the EU directives on energy efficiency (2006/32/EC) and on renewable energy sources (2009/28/EC) (Zielona Ksiegga ... 2010, p. 19, 22). The work on provisions concerning the use of nuclear

${ }^{15}$ An interview with M. Sobolewski (Bureau of Research, Chancellery of the Sejm), March 2011; an interview with D. Ledworowski (Public Board for the National Programme of Emissions' Reduction), March 2011. 


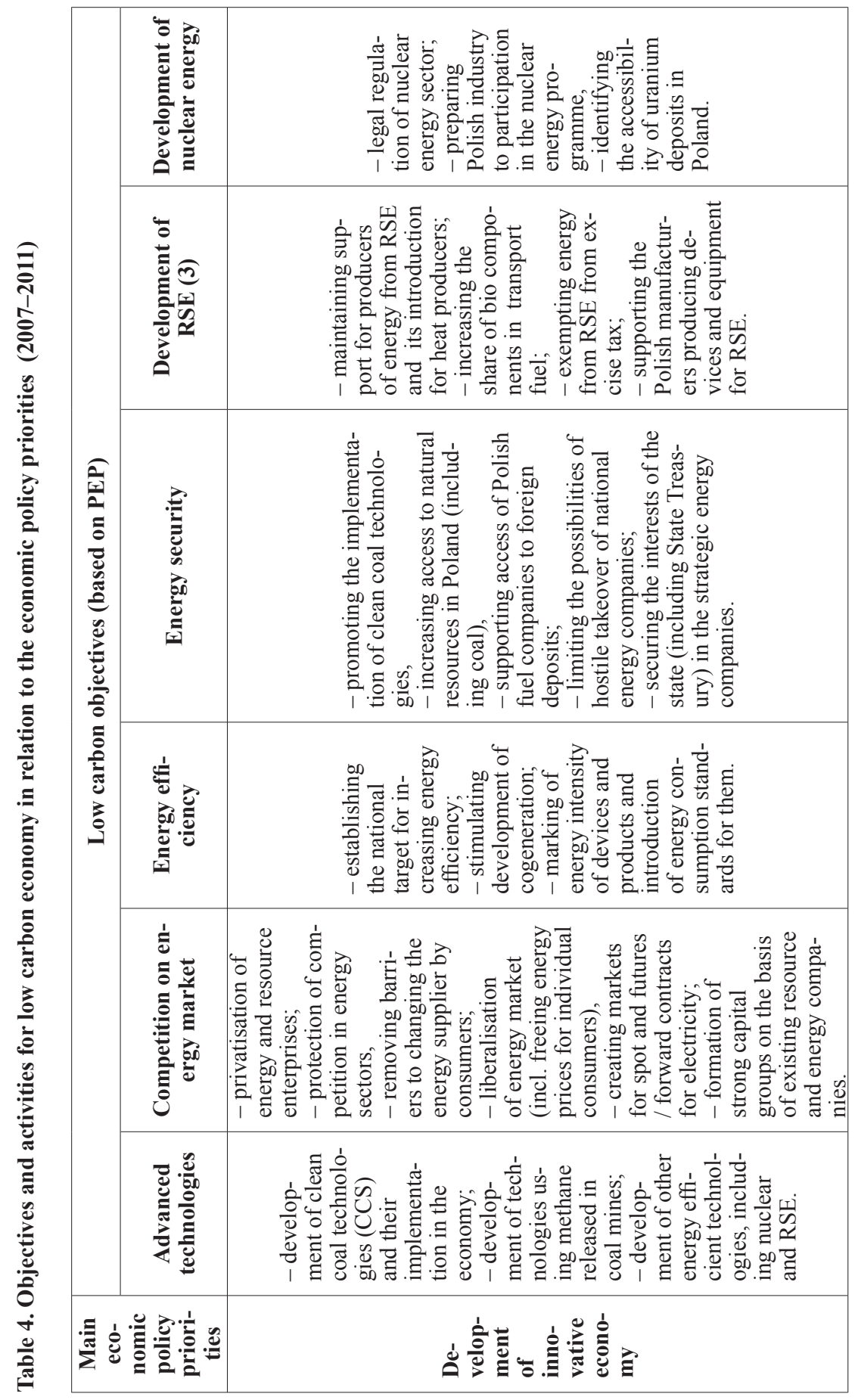

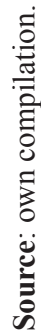




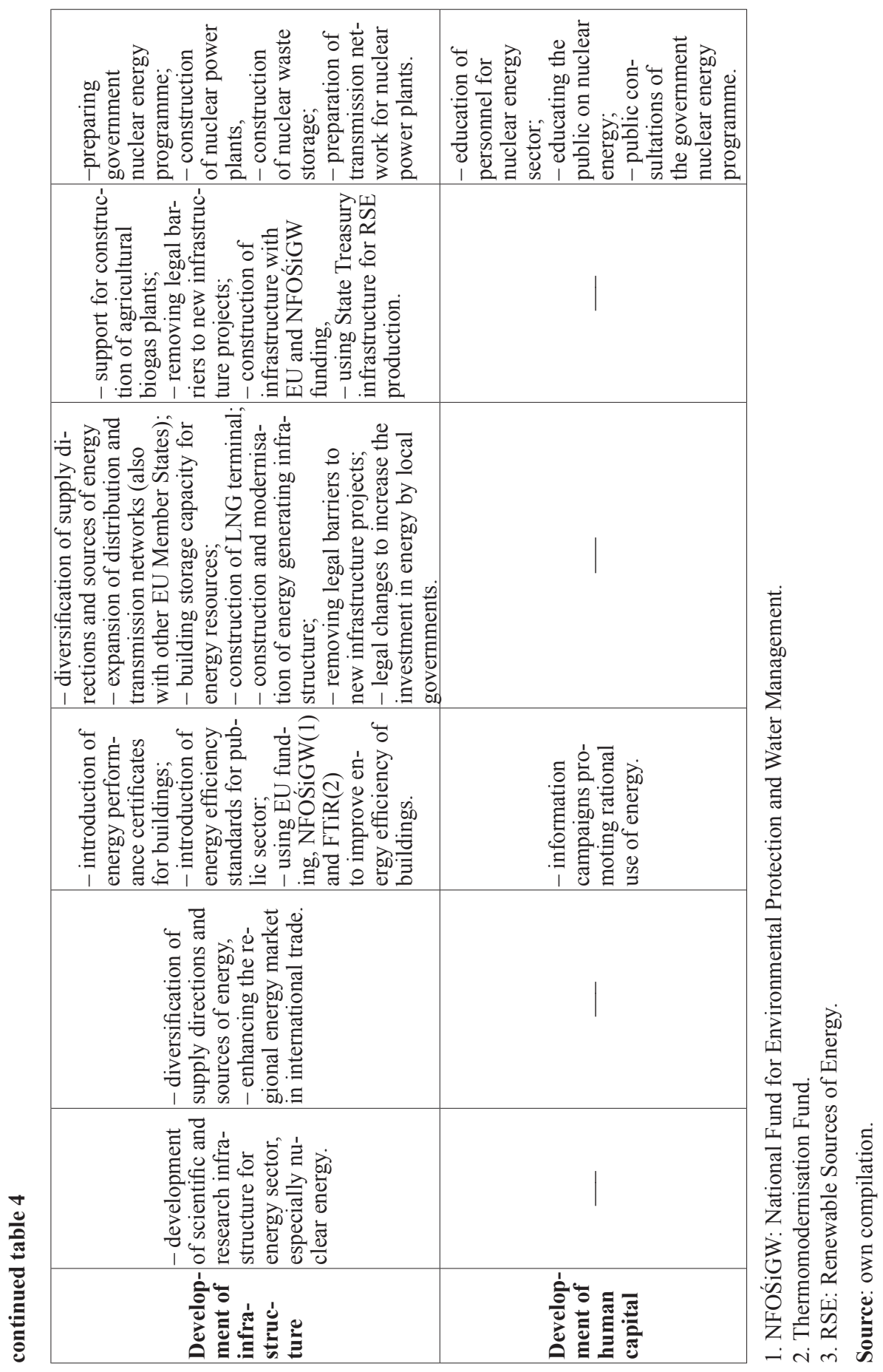


energy to generate electricity was also delayed (Zielona Księga... 2010, p. 24). As a result, Polish nuclear energy programme has been postponed by at least two years and the first nuclear power plant may start operation in 2022 at the earliest (Waldemar Pawlak... 2011).

The policy of the Polish government shifts most of the costs of adapting Polish economy to the requirements of CEP to the market. It is worth noting that this is consistent with the EU approach. The implementation of the CEP is to be achieved through investment made by enterprises, including, among others, the emission allowances auctioning system and the development of the internal energy market in the EU (Conclusions 2011, p. 3). Public investment projects are to be only of supplementary nature, for instance, when a project is not attractive enough for the market to finance or when public funds are expected to stimulate market investment. Such an approach means that investment in energy and environmental projects will cause dramatic rise in electricity prices for the industry and individual consumers [especially so as the Polish government is planning to free the energy prices for households (Uwolnienie cen... 2011)]. According to various estimates, the price rise may reach from 50 to even $100 \%$ (Transition... 2011, p. 17; Polski nie stać... 2010). This carries a threat of reduced competitiveness of the economy and decreasing the welfare of the society. It may also reduce foreign investment and lead to relocation of production from Poland to third countries. What is more, the rise of energy prices does not guarantee additional investment. Even though in the recent years the wholesale price of energy has gone up by over $60 \%$, investment in power plants has not grown (Krzysztof Żmijewski... 2010). This is related, among other things, to the specific nature of operation of the big energy groups which operate in many countries. They can use income generated on one market for investing in another. Yet another negative factor influencing investment by companies in Poland is the lack of clarity of EU regulations, especially those concerning the allocation of free emission rights for the energy sector during the transition period (2013-2020).

Without public aid, the energy sector will not be able to increase the capacity and to adjust to the requirements of the CEP. The investment potential of the sector, including its loan eligibility and the financial capability of Polish banks, is too small as compared to the needs. Experts assume (Zielona Księga ... 2010, p. 37) that if the involvement of companies were to reach the maximum level of 20 billion euro by the year 2020, at least 30 billion euro of necessary investment would still be missing. Investment is not sufficiently stimulated by the "coloured" energy certificates $s c h e m e^{16}$, under which green energy producers can

16 The "coloured" certificates scheme - introduced in Poland, among other countries, operates in such a way that green energy producers are awarded a transferable certificate for every unit of generated energy. They get income both from physical sale of energy and from trading the certificates. The prices of energy and the certificates are determined on the electricity market. The government sets the quantitative targets for the share of green energy and 
generate income by trading their certificates. According to experts ${ }^{17}$ such income exceeds 1 billion euro per annum, but the weakness of the scheme lies in the fact that while supporting the producers, it does not ensure that new investment in the energy sector is made. Another consequence of Europeanisation in the area under discussion is neglecting investment in the coal-mining sector, which resulted in Poland becoming a net importer of coal (Polska... 2011). This poses a serious threat to the energy security of the economy.

Experts point out (Zielona Ksiega... 2010, p. 26) to the insufficient use of the domestic financial instruments. The scope of support granted by the National Fund for Environmental Protection and Water Management [NFOŚiGW] and the Thermomodernisation Fund [FtiR] is too small. The domestic instruments have at their disposal mainly the funds from the sale of emission allowances (the so called Green Investment Scheme ${ }^{18}$ ) or substitution fees or penalties connected with fulfilling the obligation to acquire and submit for redemption the energy certificates of origin (the so called "coloured" certificates scheme). They are thus financed, to a great extent, by the business. In the Polish reality the funds are quite substantial (see table 5), although still insufficient in relation to the needs of low carbon economy. They have been designed mainly to address two objectives: improve energy efficiency and RSE. The relevant government agencies and ministries are not very good at coordinating individual activities. This is a consequence of the lack of a proper institutional system for national development policy (a system that would not be related to the implementation of the EU cohesion policy). In addition, at the time of budget restrictions connected with excessive public debt - the energy sector is one of the places where funds are sought to support the state budget. The fiscal burdens imposed on energy in Poland are among the highest in the EU and exceed 23\% (Polski nie stać... 2010). In such a situation even the income from the sale of $\mathrm{CO}_{2}$ emission rights is threatened, as, according to experts (Miliardy... 2011), instead of being used for investment in energy sector, it might go straight to the state budget. And these are potentially amounts reaching from approximately 1.3 billion in 2013 to over 3.3 billion euro in 2020 .

the market participants who sell energy to end users either buy an appropriate number of certificates or they have to pay a penalty or a substitute fee. These are paid to the state budget and are in part used for co-funding low carbon investment projects (see Gnatowska 2010; Żmijewski 2011a).

${ }^{17}$ An interview with K. Żmijewskim (Secretary General of the Polish Board for the National Programme of Emissions' Reduction), March 2011.

${ }^{18}$ GIS - Green Investment Scheme is derived from the emission trading mechanism agreed in the Kyoto Protocol. It is connected with "earmarking" of funding acquired from the sale of the excess of emission units in order to ensure that they are spent on clearly defined objectives related to environmental protection in the state of the units' seller. 
Thus, the effectiveness of the domestic financial instruments may be very moderate. The forecasts related to activities implemented by NFOŚiGW indicate (NFOŚiGW... 2010, p. 16) that, thanks to the investment made from the Fund, the efficiency of the end use of energy will, by the year 2016, increase by only approx. 0.67 Mtoe, which accounts for just 15 percent of the national target. Meanwhile, the reduction of $\mathrm{CO}_{2}$ emissions as a result of all NFOŚiGW activities (including also the cohesion policy instruments) will, over the next seven years (2011-2017), amount only to 5 million tons (NFOŚ $i G W \ldots$.. 2010, p. 20). It is a rather modest achievement, considering that the annual limit of free emission allowances for Poland in the years 2008-2012 is more than 208 million tons.

A very low level of domestic public funds involvement in innovative projects and in development of new low carbon technologies should also be noted. It is only limited to a small number of research programmes funded by the Ministry of Science and Higher Education (table 5) ${ }^{19}$. This is indeed a wider problem of the economic policy in Poland, where - so far - no national innovation scheme has been created, no scheme that would initiate research and development work suited to the goals of the national development policy and support the transfer of innovation and technology to business. In addition, only limited activities are undertaken in support of the development of human resources, including training and information activities, to meet the needs of low carbon economy (table 5) ${ }^{20}$.

In this situation, the main source of public funding for investment in Poland are EU funds. In the years 2007-2013 Poland has been the greatest beneficiary of the cohesion policy and may receive more than 67 billion euro from the EU budget (these funds must be supplemented with the mandatory domestic contribution). These funds have been, for many years, the main and in a number of areas, the only source of funding for development investment (Grosse 2006). Specialists claim ${ }^{21}$ that they are rather loosely related to the CEP objectives and their support for the development of low carbon economy is not strong enough. Instead, they indirectly contribute to the increase of emissions mainly because most of the funds support the development of transport infrastructure. This is an example of a lack of homogeneity or even contradiction between various trends of Europeanisation. Under the cohesion policy implemented in the years 2007-2013, the main instruments of support for the energy policy (including low

${ }^{19}$ Examples of research programmes implemented in the years 2007-2010: Materials and technologies for hydrogen management development basing on the industrial process gases; Chemistry of prospect processes and by-products of coal conversion; Supercritical coal-fired power units; Modern technologies for the energy use of biomass and bio-degradable waste. See Ocena realizacji... 2009, p. 16.

${ }^{20}$ A similar view: Zielona Księga, (2010, p. 16).

${ }^{21}$ Statement made by A. Kassenberg during the conference „Droga ku efektywnemu wdrażaniu PEK" [Towards effective implementation of CEP], 18 November 2009, Warsaw. 
carbon economy) have been the Operational Programme Infrastructure and Environment (OP IE) and the sixteen regional operational programmes (16 ROP). They have been designed mainly to address infrastructure objectives, concerning improvement of energy efficiency, energy security and RSE (table 5). For these objectives, under those programmes, only less than $2.5 \%$ of all cohesion policy funding in Poland has been allocated. Just to compare, for the development of transport infrastructure, during the same time, more than $24 \%$ of funds have been allocated. Moreover, the European policy does not sufficiently develop low carbon technologies or support their application by business. Thus, it only marginally contributes to the achievement of one of the main goals of the CEP, namely, the promotion of innovative technology within the framework of "green" economy (Analysis... 2010, pp. 5, 12). This is a serious problem of cohesion funds, which fail to sufficiently stimulate the development of innovative and competitive economy in the more slowly developing countries of Central Europe (Grosse 2010b). As a result, the support from the cohesion policy (under its current investment direction) is definitely insufficient when set against the needs of the development of low carbon economy. If one assumed that the adaptation to the CEP requirements in Poland entails investment in the order of 100 billion euro then the European Union support available under the cohesion policy will amount to less than $2 \%$ of this sum.

\section{Conclusions}

The economic crisis (2008-2010) has made the economic competition more fierce, both on the common market and globally. At the same time, it has intensified the activity of politicians, aimed at finding competitive advantage for European businesses. A good example of such a trend is the EU climate policy. One of its goals is to build economic competitiveness in the area of low carbon technologies, and especially to use the existing potential of some European economies with respect to technological advancement and access to clean energy Sources: The rules of the CEP produce unequal consequences for individual Member States. They bring benefits to the better developed countries with technological advantage, and, at the same time, they impose excessive cost burden on the less developed economies based on coal, thus decreasing their cost-effectiveness. This way, European regulations may support competitiveness of some EU Member States on the common market, and simultaneously weaken others. This is of great importance for employment and the rate of economic growth in individual countries.

The phenomenon is confirmed by earlier research on Europeanisation (Höpner et al. 2007, pp. 8, 22). Its results show that European regulations and policies have strong impact on national economic policies and on the institutional sys- 


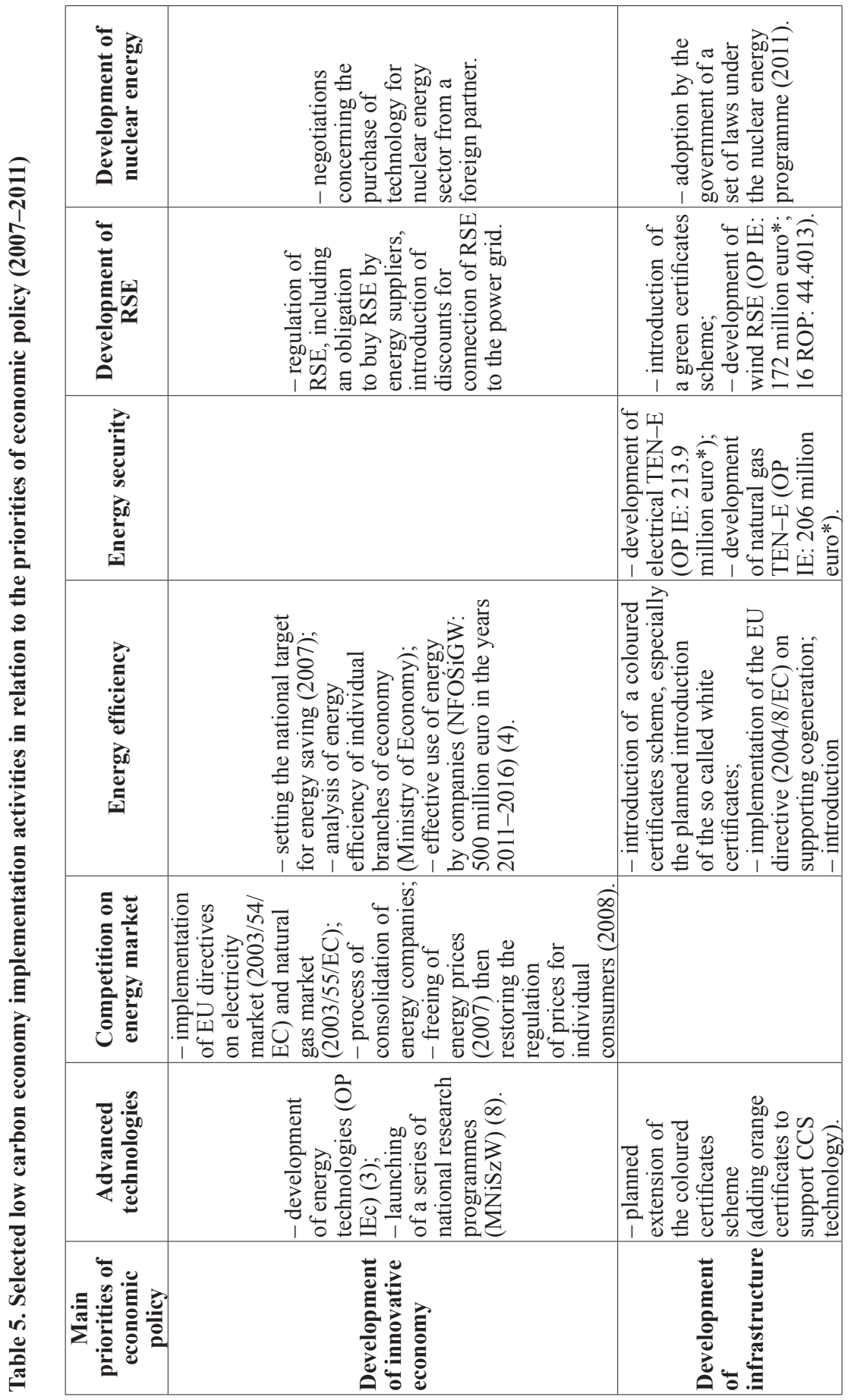




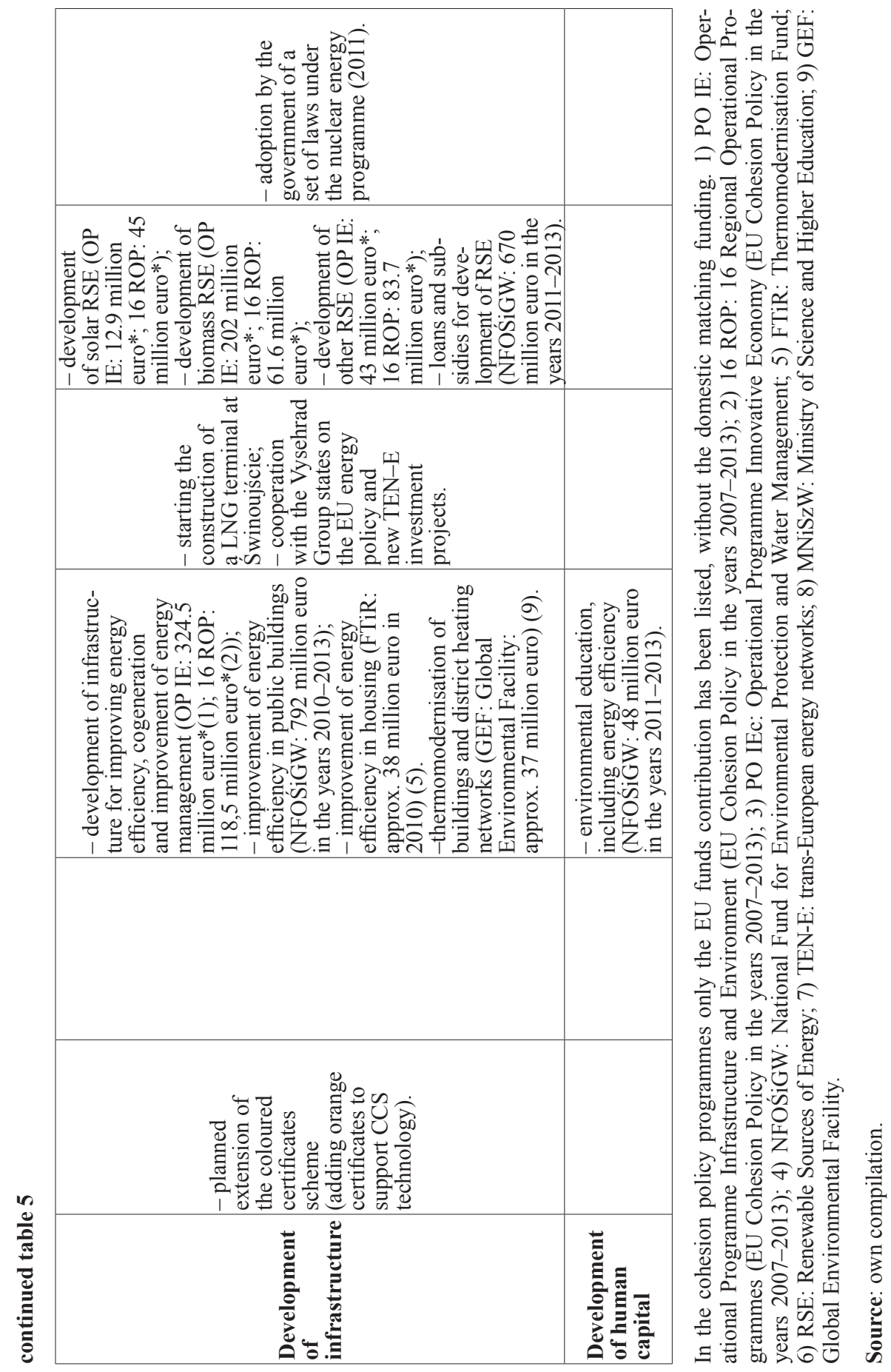


tem of the economy [the national model of capitalism (Hall et al. 2001; Amable 2003, pp. 103-114, 176; Alber 2006)]. This impact varies depending on local conditions. Wherever the EU policy is not consistent with the local logic of the economic system, it leads to serious costs, decreasing of the system's internal rationality of operation or to its gradual de-institutionalisation. This is also an example of individual states using European policies to maximise their benefits on the common market, among others, through such design of EU regulations that will strengthen their national competitive advantage and reduce the possible costs of introducing the EU law (Smith 2005; Callaghan et al. 2005). This requires the national governments to be politically active on the EU forum and to ensure close coordination with the national development policy.

An additional difficulty resulting from Europeanisation are the serious constraints concerning granting of public aid by national governments. EU regulations do permit granting of aid to the sectors susceptible to high cost of electricity or transfer of production abroad. The provisions, however, are not very precise and, what is more, the Polish state has limited capability to grant such support in a situation of growing public debt. On the other hand, the cohesion policy funding, designed for the less developed Member States, only to a limited extent supports the development of low carbon economy. In particular, it is not good at stimulating the development of "green" economy where competitiveness is based on the use of modern technology.

The Europeanisation processes related to climate policy are particularly disadvantageous for Polish economy. Its competitiveness is based primarily on low production costs and at the same time, the main source of energy is a high-emission type of fuel - coal. Thus, a consequence of implementing the CEP in Poland and of pursuing the current Polish economic model may be the escape of some industries outside the country, also to other EU Member States. Another possibility is the reduction of the GDP growth rate and increase of unemployment. In this situation, it is a challenge for the Polish government either to mitigate the EU CEP or to fundamentally change the model of development for the national economy.

This will require a coherent long-term economic policy and intensive political activity on the EU level; whereas, currently in Poland there exists neither a long-term strategy for national development nor a policy for the development of low carbon economy. All the action undertaken in this area takes place in response to the initiatives of European policies and is, to a great extent, limited to implementing EU regulations. Thus, what happens is the gradual, although delayed, implementation of the CEP requirements, yet without proper support for national enterprises. What is also missing is such a re-orientation of the investment processes that would strengthen the competitiveness of national economy. Consistently with the philosophy adopted under the CEP - the policy of the Polish government shifts most of the costs related to adapting the national 
economy to the Package requirements to the market. Business is supported by the state budget only to a very limited extent. The activities of individual public bodies focus on the implementation of narrowly defined sector strategies and are not properly coordinated, either at the planning or at the implementation stage. Additional difficulty is the lack of continuity in the policy of the state by subsequent governments.

Another problem is the weakness of the political activity of the Polish government at the EU level; whereas, in the context of European integration, it is an indispensable element of an effective economic policy of every Member State. The conclusions of this article show that the political activity of subsequent Polish governments in this respect is passive and severely delayed. Inter-ministerial coordination fails, which is a result of the poor system of EU policy management by Polish government. The coordination is mostly carried out by the Ministry of Foreign Affairs ${ }^{22}$, while examples of other countries prove that it is much more effective if the responsibility for coordination lies with the chancellery of the head of the government (James 2010). The weakness of Polish European policy is partly a result of the lack of the proper national economic policy. As a result, Poland adopts a reactive approach towards initiatives originating at EU institutions. This may be shown by a number of strategic documents which are drafted almost only for the purpose of the implementation of EU policies.

In connection with the EU climate policy, Poland faces a challenge of a fundamental change of its economic model - to low carbon economy based on innovation and environment-friendly technologies. This requires the preparation of a long-term policy of the development of low carbon economy. It is necessary to make an in-depth analysis and diagnosis of the condition of Polish economy as well as assess the consequences of implementing the CEP for individual sectors and regions. This policy cannot be limited only to the implementation of the Package requirements but it must, first of all, aim to strengthen the competitiveness of the national economy. It should not involve only the energy sector but must also cover other sectors of the economy ${ }^{23}$. The goal of such a policy should be to support development research and the development of low carbon technologies $^{24}$, as it is one of the main priorities of the EU climate policy. For this purpose, a strong National Innovation Scheme should be created, with implementation of low carbon economic policy of the government as one of its priorities.

${ }^{22}$ See Act dated 27 August 2009 on the European Affairs Committee, „Journal of Laws” 2009, No. 161, item 1277.

${ }^{23}$ An interview with D. Kulczycka (PKPP Lewiatan), March 2011.

${ }^{24}$ An interview with Prof. K. Żmijewski (Secretary General of the Public Board for National Programme of Emissions' Reduction), March 2011, an interview with D. Kulczycka (PKPP Lewiatan), March 2011. 
Government policy should support energy efficiency and investment projects focusing on the development of renewable sources of energy ${ }^{25}$. In both cases, there is a relatively big potential for such activity in Poland. Experts ${ }^{26}$ recommend, among other solutions, a reform of the coloured certificates scheme so that it could support not only the producers but, first of all, those who invest in the new energy generation capacity. In addition, the certificate scheme should be more effective in reducing the price of energy ${ }^{27}$. The existing administrative barriers to the development of RES should be removed, mechanisms of publicprivate partnership in this area should be developed and technological solutions implemented in microscale should be supported (such as solar panels, biogas plants, etc. $)^{28}$. The government should, to a greater extent, encourage people to save energy, also by imposing an obligation on the public sector to increase energy efficiency (e.g. in public buildings) ${ }^{29}$. The development of energy market should be supported, also through construction of cross border interconnectors which will make it possible to benefit from the offer of foreign energy produc$e^{30}{ }^{30}$. In addition, public aid should be granted (within the scope of the EU law) to sectors at risk of production transfer abroad. The point is to support the necessary investment that the companies need to make. An important element of the government policy should be to divide the funds acquired under the community emissions trading scheme, which, under the EU law, may be allocated, for example, to the development of RES, energy efficiency and CCS installations. These funds should not be used as a remedy to excessive deficit or public debt. A system of "green" public procurement could also be developed, so that the criteria of energy efficiency and use of RSE were taken into account ${ }^{31}$. The state's economic policy should also be more focused on developing the services sector and the development of human resources for the low carbon economy.

${ }^{25}$ An interview with Prof. K. Żmijewski (Secretary General of the Public Board for National Programme of Emissions' Reduction), March 2011; an interview with A. Kassenberg (Institute for Sustainable Development), March 2011.

${ }^{26}$ An interview with M. Sobolewski (Bureau of Research, Chancellery of the Sejm), March 2011; an interview with Prof. K. Żmijewski (Secretary General of the Public Board for National Programme of Emissions' Reduction), March 2011.

${ }^{27}$ An interview with A. Kassenberg (Institute for Sustainable Development), March 2011.

${ }^{28}$ Ibidem.

${ }^{29}$ An interview with M. Sobolewski (Bureau of Research, Chancellery of the Sejm), March 2011; an interview with A. Kassenberg (Institute for Sustainable Development), March 2011.

${ }^{30}$ An interview with M. Sobolewski (Bureau of Research, Chancellery of the Sejm), March 2011; an interview with D. Kulczycka (PKPP Lewiatan), March 2011; an interview with D. Ledworowski (Public Board for National Programme of Emissions' Reduction), March 2011.

${ }^{31}$ An interview with D. Kulczycka (PKPP Lewiatan), March 2011. 
Appropriate institutions should be built for effective coordination and implementation of the government's low carbon policy. As early as at the planning stage, the low carbon economy strategy could be used for proper coordination of activities between sectors and for binding this strategy even more to the main goals of the government's economic policy. It would thus become a "secondlevel" strategy, coordinating the leading national development strategy with the sector-specific documents. An appropriate system is also needed for implementation, monitoring and evaluation of national development policies. The system of institutions created for the implementation of the cohesion and the regional policies could be used for this purpose. I have in mind here, for instance, application of territorial (voivodship) contract instruments or regional operational programmes implemented by voivodship authorities. Using the instruments of regional policy to implement the low carbon economic policy of the government is driven by the specific territorial nature of the country, which requires flexible instruments. In addition, a number of activities aimed at improving energy efficiency or development of RES may be successfully carried out on the regional or even local scale. Appropriate incentives should be introduced for local governments to encourage their greater involvement in action for low carbon economy ${ }^{32}$. Another instrument may be the above mentioned innovation policy of the government and the creation of a strong National Innovation Scheme. The activities under the Scheme may be also partially implemented in a decentralised way, with the support of voivodship authorities. A reform of the public finance system is absolutely necessary in order to increase the pool of funds for investment related to low carbon policy (Grosse 2010a). Other funding for this policy may come from the Community Emissions Trading Scheme and the Green Investment Scheme ${ }^{33}$.

Another challenge is to improve the political activity of the Polish government at the EU arena, by taking advantage of the Polish Presidency in the EU (in 2011), in order to play a more active part in developing detailed solutions implementing the CEP. Experts agree ${ }^{34}$ that at the current stage of the European debate, there is little chance to re-negotiate the CEP to make it more beneficial for Polish economy. Nevertheless, they suggest that certain action should be taken, for instance, to strive for reducing the cost of emission allowances, including imposing limits on the purchase of allowances by entities from outside the EU or

\footnotetext{
${ }^{32}$ An interview with T. Chruszczow (Ministry of Environment), March 2011.

${ }^{33}$ See footnote 18 .

${ }^{34}$ An interview with A. Kassenberg (Institute for Sustainable Development), March 2011; an interview with M. Sobolewski (Bureau of Research, Chancellery of the Sejm), March 2011.
} 
by investment-speculation funds. They also suggest that the unused parts of the allocation could be transferred from non-ETS area to EU ETS or outside the EU (the so called flexible trading \& offset model) (Karaczun et al. 2009, pp. 46-47; Żmijewski 2011b, p. 5). It is a challenge for Polish diplomacy to participate in the negotiations over the future of EU policy after the year 2020 related to the road map for competitive and low carbon economy ${ }^{35}$. The active participation of the government in the works on the details of the European industrial policy referred to in "Europe 2020" may be of great importance. In addition, the EU cohesion policy should be re-oriented towards supporting low carbon economy objectives, and, especially, the development of low carbon technologies and their economic application in the least developed EU Member States ${ }^{36}$. Unfortunately, such tasks feature neither in the Polish government's position on the future of the cohesion policy after 2013 (The position... 2010), nor in the preliminary priorities for the Polish Presidency of the European Union Council (Preliminary priorities... 2011).

\section{Literature}

A New Growth Path for Europe 2011, European Climate Forum, Potsdam.

A Roadmap for moving to a competitive low carbon economy In 2050, Communication from the Commission to the European Parliament, the Council, the European Economic and Social Committee and the Committee of the Regions, COM(2011) 112/4, Brussels 8.3.2011.

Alber J. (2006), The European Social Model and the United States, „European Union Politics”, vol. 7, No. 3, pp. 393-419.

Amable B. (2003), The Diversity of Modern Capitalism, Oxford University Press, Oxford-New York.

Analysis of options to move beyond 20\% greenhouse gas emission reductions and assessing the risk of carbon leakage, Communication from the Commission to the European Parliament, the Council, the European Economic and Social Committee and the Committee of the Regions, COM (2010) 265 final, Brussels 26.5.2010.

Börzel T. A. (2005), Europeanization: How the European Union Interacts with its Member States, [in:] The Member States of the European Union, (ed.) S. Bulmer, Ch. Lequesne, Oxford University Press, Oxford-New York.

${ }^{35}$ A Roadmap for moving to a competitive low carbon economy In 2050; an interview with A. Błachowicz (Ministry of Environment), March 2011.

${ }^{36}$ An interview with A. Kassenberg (Institute for Sustainable Development), March 2011; an interview with D. Ledworowski (Public Board for National Programme of Emissions' Reduction), March 2011. 
Börzel T. A., Risse T. (2007), Europeanization: The Domestic Impact of EU Politics, [in:] Handbook of European Union Politics, (ed.) Jørgensen K. E., Pollack M. A., Rosamond B. J., Sage, London.

Bruksela utrudnia darmowq emisje $\mathrm{CO}_{2}$, „Rzeczpospolita”, 24-01-2011.

Callaghan H., Höpner M. (2005), European Integration and the Clash of Capitalisms: Political Cleavages over Takeover Liberalization, „Comparative European Politics”, No. 3, pp. 307-332.

Climate change: Commission invites to an informed debate on the impacts of the move to $30 \%$ EU greenhouse gas emissions cut if and when the conditions are met, European Commission, Brussels, IP-10-618, 26 May 2010.

Conclusions, European Council, 4 February 2011, EUCO 2/11, Brussels.

Costa O. (2008), Is climate change changing the EU? The second image reversed in climate politics, „Cambridge Review of International Affairs”, vol. 21, No. 4, pp. 527-544.

Cowles M. G., Caporaso J. A., Risse T. (ed.) (2001), Transforming Europe: Europeanization and Domestic Change, Cornell University Press, Ithaca, NY.

Członek zarzqdu zapowiada, że Vattenfall sprzeda swój biznes w Polsce, „Gazeta Wyborcza”, 20-01-2011.

Czy zbankrutujemy przez $\mathrm{CO}_{2}$ ? „Polska - The Times”, 1-12-2010.

Efektywność wykorzystania energii w latach 1998-2008, (2010) Central Statistical Office, Warszawa.

Elektrownie czekaja w napięciu, „Rzeczpospolita”, 28-01-2010.

Energia ze źródel odnawialnych w 2009 r., (2010) Central Statistical Office, Warszawa.

Energy and $\mathrm{CO}_{2}$ emissions scenarios of Poland (2010), International Energy Agency, OECD.

Europe 2020. A strategy for smart, sustainable and inclusive growth, European Commission, $\operatorname{COM}(2010) 2020$ final version, Brussels 3.3.2010.

Featherstone K., Radaelli C. M. (ed.) (2003), The Politics of Europeanization, Oxford University Press, Oxford-New York.

Gnatowska R. (2010), Charakterystyka polskiego systemu certyfikacji pochodzenia energii elektrycznej, „Polityka Energetyczna”, vol. 13, Booklet 2, pp. 145-155.

Gradziuk A., Wyciszkiewicz E. (2010), Kopenhaski pat: klimatyczny dylemat Unii Europejskiej, „Polski Przegląd Dyplomatyczny”, No. 1 (53), pp. 37-60.

Grosse T. G. (2006), An Evaluation of the Regional Policy System in Poland: Challenges and Threats Emerging from Participation in the EU's Cohesion Policy, „European Urban and Regional Studies", vol. 13, No. 2, 151-165.

Grosse T. G. (2010a), Bariery dla skoku cywilizacyjnego Polski 2010-2030, [in:] Kukliński A., Pawłowski K., Woźniak J. (ed.): Polonia quo vadis? Biblioteka Małopolskiego Obserwatorium Polityki Rozwoju, 3rd vol., Kraków, pp. 93-115.

Grosse T. G. (2010b), EU Cohesion Policy and the peripheries of the New Member States, [in:] Regional Development in Central and Eastern Europe, Gorzelak G., Bachtler, Smętkowski J. M. (eds.), Routledge, London-New York, pp. 313-328.

Hall P., D. Soskice (ed.) (2001), Varieties of Capitalism: The Institutional Foundations of Comparative Advantage, Oxford University Press, Oxford-New York.

Hedegaard backtracks on EU climate goals, EurActiv, 27 May 2010.

Hongyuan Y. (2009), Two Logics of Climate Change Games: Environmental Governance and Know-How Competition, [in:] Gradziuk A., Wyciszkiewicz E. (ed.), Energy Security and Climate Change. Double Challenge for Policymakers, Polish Institute of International Affairs, Warsaw, pp. 125-152.

Höpner M., Schäfer A. (2007), A New Phase of European Integration. Organized Capitalism In Post-Ricardian Europe, MPIfG Disscussion Paper 07/04. 
James S. (2010), Adapting to Brussels: Europeanization of the core executive and the 'strategic projection' model, „Journal of European Public Policy”, vol. 17, No. 6, pp. 818-835.

Jeszke R., Błachowicz A., Smol E., Sikora P., Lizak S., Pyrka M. (2009), Wybrane aspekty wdrażania Pakietu energetyczno-klimatycznego [Selected aspects of the implementation of the Climate and Energy Package], KASHUE-KOBiZE, Warsaw.

Karaczun Z. M., Kassenberg A., Sobolewski M. (2009), Polityka klimatyczna Polski-wyzwanie XXI wieku, Polski Klub Ekologiczny, Warsaw.

Klonowski D. (2010), The effectiveness of government-sponsored programmes in supporting the SME sector in Poland, „Post-Communist Economies”, vol. 22, No. 2, pp. 229-245.

Krajowy Plan Dziatań dotyczacy efektywności energetycznej (EEAP) (2007), Ministry of Economy, Warsaw.

Krajowy Program Reform na lata 2008-2011 na rzecz realizacji Strategii Lizbońskiej [National Reform Programme for the years 2008-2011 for the implementation of Lisbon Strategy] (2008), Ministry of Economy, Warszawa.

Łakoma A., Baca K. (2011), Plany UE szkodzq elektrowniom, „Rzeczpospolita daily”, 11-03-2011.

Mair P. (2004): The Europeanization dimension (Review), „Journal of European Public Policy”, 11(2): 337-348.

Miliardy ze sprzedaży uprawnień do emisji $\mathrm{CO}_{2}$, „Rzeczpospolita”, 02-02-2011.

Narodowe Strategiczne Ramy Odniesienia 2007-2013 [National Strategic Reference Framework] (document approved by a decision of the European Commission) (2007), Ministry of Regional Development, Warszawa.

NFOŚiGW na rzecz efektywności energetycznej (2010), NFOŚiGW.

Ocena potencjatu redukcji emisji gazów cieplarnianych w Polsce do roku 2030 (2009), McKinse-\&Company, Warsaw.

Ocena realizacji Polityki Energetycznej od 2005 roku, Ministry of Economy (2009), Warsaw.

Olsen J.P. (2002), The many faces of Europeanization, „Journal of Common Market Studies”, No. 40 (5), pp. 921-952.

Piszczatowska J. (2011), Polska potrzebuje nowych elektrowni, „Rzeczpospolita”, 03-02-2011.

Piszczatowska J., Baca K. (2010), Firmy wstrzymuja węlowe inwestycje, „Rzeczpospolita”, 08-02-2010.

Polityka ekologiczna państwa w latach 2009-2012 z perspektywa do roku 2016 [National Environmental Policy in the years 2009-2012 with the perspective by the year 2016 (2008), Ministry of Environment, Warsaw.

Polityka energetyczna Polski do 2030 roku (2009), Ministry of Economy, Warsaw.

Polityka Klimatyczna Polski. Strategie redukcji emisji gazów cieplarnianych w Polsce do roku 2020 (2003), Ministry of Environment, Warsaw, a document adopted by the Council of Ministers on 04 November.

Polska 2030 (2009), Prime Minister's Chancellery, Warsaw.

Polska nadal importerem węla netto, „Rzeczpospolita”, 19-01-2011.

Polski nie stać na pakiet $3 \times 20$ - wywiad z M. Swora, Prezesem Urzędu Regulacji Energetyki (2010), „Energetyka cieplna i zawodowa”, No. 4.

Preliminary piorities of the Polish Presidency approved, http://prezydencjaue.gov.pl, 20.03.2011.

Pyrka M., Lizak S. (2009), Zjawisko ucieczki emisji w sektorach energochłonnych w Polsce $w$ kontekście zmian wprowadzanych $w$ systemie EU ETS na lata 2013-2020 [Emission leakage in the energy-intensive sectors in Poland in the context of the changes introduced to the EU ETS for the years 2013-2020], KASHUE-KOBiZE, Warsaw.

Radaelli C. M. (2003), The Europeanization of Public Policy, in The Politics of Europeanization, (ed.) Featherstone K., Radaelli C. M., Oxford University Press, Oxford-New York.

ReRisk Regions at Risk of Energy Poverty, The ESPON 2013 Programme, Version 31/03/2010. 
Scheipers S., Sicurelli D. (2007), Normative Power Europe: A Credible Utopia?, JCMS, vol. 45, No. 2, pp. 435-457.

Schreurs M. (2004), The climate change divide: the European Union, the United States, and the future of the Kyoto Protocol, [in:] Vig M. and Faure N. J. (eds.), Green giants? Environmental policies of the United States and the European Union, MIT Press, Cambridge, Massachusetts, pp. 207-230.

Schreurs M., Tiberghien Y. (2007), Multi-level reinforcement: explaining European Union leadership in climate change mitigation, „Global Environmental Politics”, vol. 7, No. 4, pp. 19-46.

Smith M. P. (2005), Germany's Quest for a New EU Industrial Policy: Why it is Failing, „German Politics”, vol. 14, Nr 3, pp. 315-331.

Smol E. (2010), Metodyka wraz z przykładowym obliczeniem ,,limitu” krajowej emisji gazów cieplarnianych dla Polski na lata 2013-2020, KASHUE-KOBiZE, Warszawa.

Strategia Rozwoju Kraju 2007-2015, [National Development Strategy] (2006), Ministry of Regional Development, Warszawa.

The position of the Government of Poland on the future of the cohesion policy after 2013. „Polityka Spójności jako skuteczna, efektywna i terytorialnie zróżnicowana odpowiedź na wyzwania rozwojowe Unii Europejskiej", adopted by the Council of Ministers on 18 August 2010.

Transition to a Low-emissions Economy In Poland (2011), World Bank, Washington 2011.

Unia uderzy w inwestycje w polskich elektrowniach, „Rzeczpospolita”, 15-02-2011.

Uwolnienie cen prqdu dla konsumentów w 2012 roku, ,, Rzeczpospolita”, 01-03-2011.

Waldemar Pawlak forsuje pakiet atomowy, „Rzeczpospolita”, 17-01-2011.

Założenia aktualizacji Strategii Rozwoju Kraju 2007-2015 [Proposals for the update of the National Development Strategy] (2008), Ministry of Regional Development, Warszawa.

Założenia Narodowego Programu Redukcji Emisji Gazów Cieplarnianych, Ministry of Economy, Warsaw 2010.

Zielona Księga Narodowego Programu Redukcji Emisji Gazów Cieplarnianych (2010), [Green Book of the National Programme for the Reduction of Greenhouse Gases Emissions], Społeczna Rada Narodowego Programu Redukcji Emisji, Warsaw.

Żmijewski K. (2011a), ABC kolorowej certyfikacji, „Materiały Budowlane”, No. 1, pp. 8-11.

Żmijewski K. Sektor energetyczny potrzebuje 100 mld euro, „Rzeczpospolita”, 8-11-2010.

Żmijewski K. (2011b), Zagrożenie problemem carbon leakage w Polsce [Risk of carbon leakage in Poland], E. Kwiatkowski Institute, Warsaw. 
